\title{
Determining Factors of Potential Economy Sectors of Bantaeng Regency in South Sulawesi Province of Indonesia: An Analysis Using the Location Quotient Approach
}

\author{
Willy Arafah ${ }^{1} \&$ Ryan Corinus Dato Matheos ${ }^{2}$ \\ ${ }^{1}$ University of Trisakti, Indonesia \\ ${ }^{2}$ Engineer at Agency for the Assessement and Application of Technology, BPPT, Indonesia \\ Correspondence: Willy Arafah, University of Trisakti, Indonesia. E-mail: willy.arafah@gmail.com
}

Received: April 25, 2017

Accepted: May 21, 2017

Online Published: June 7, 2017

doi:10.5539/ijbm.v12n7p183

URL: https://doi.org/10.5539/ijbm.v12n7p183

\begin{abstract}
Bantaeng Regency, one of the regencys in South Sulawesi Province, has some potential economy sectors to be developed. In order to know those potential economy sectors, one of the economy analysis which can be used is the Location Quotient analysis. In this research, the analysis will use Static Location Quotient (SLQ) and Dynamic Location Quotient (DLQ). The SLQ method is used to determine the base sectors (leading sectors) in Bantaeng Regency at one period of time. While DLQ method is used to determine whether a sector that is superior over a period of time are leading sectors for the period of time that will come. The analysis showed that in the year 2013-2014 the Trade and Retail sector; Car and Motorcycles Repair sector; Real Estate sector; Government Administration sector; Defence and Compulsory Social Security; and Other Services Sector is the leading economy sector in Bantaeng Regency. And in the year 2014-2015, the Trade and Retail sector; Cars and Motorcycles Repair sector; Real Estate sector; Service Sector Health and Social Work; and Other Services Sector is the leading economy sector in Bantaeng Regency.
\end{abstract}

Keywords: Ttrade and retail sector, cars and motorcycles repair sector, real estate sector, service sector health and social

\section{Preliminary}

Accordance with the mandate of regional autonomy, each local government (the city and the regency government) was given by the central government some authority to explore its potential resources. Each region has different economy advantages, as well as the source of growth for its region. In this context, the local government is considered to be able to explore the economy advantages, which is the source region of excellence, to ensure that the local economy can grow faster in accordance with the availability of potential resources and ability to grow. Until now, the sectoral approach is still one of the strategies in regional development. The sectoral approach or commonly known as the base sector approach is more emphasis on the selection of the economy sectors that can be more precise and faster acting as regional economy driver, labour absorbing and poverty alleviation.

The sectoral approach is more focused on improving the productivity of economy sectors through the priorities development program in the local government policy. Therefore, the analysis of the sector which is the base/economic advantage in an area to be very important as a consideration in formulating development policies. Thus, it will be known which sector is the basic sector and its role in promoting economy growth in the region.

Arsyad (1999) revealed that differences in local conditions carrying implications for the mode of application development in the region. Regional economy development policies which are set in an area must be adapted to the local conditions (problems, needs and potential) of the area.

This analysis was conducted to map out potential economy sectors in Bantaeng Regency, located in South Sulawesi Province. The analysis technique which used is first to determine the base sectors in each period and subsequent mapping the potential economy sectors in the running period of the time. The process of determining the sectors base becomes important because, according to Blakely (1989) and Kuncoro (2004) defining the economic basis is a task that needs to be done in the first stage in the process of regional economy development 
planning.

\section{Methodology}

\section{1) The Static Location Quotient and the Dynamic Location Quotient Method}

To determine the base sectors (seed) of an area over a certain time period, in this analysis method is used SLQ by the following equation (Yuwono, 2000):

$$
S L Q_{i j}=\left[\mathrm{y}_{i j} / \Sigma_{i} \mathrm{y}_{i j}\right] /\left[\Sigma_{j} \mathrm{y}_{i j} / \Sigma_{i} \Sigma_{j} \mathrm{y}_{i j}\right]
$$

Where:

$\mathrm{SLQ}_{i j}$ : the value that indicates the level of specialization in sector $i$ in Bantaeng Regency;

$\mathrm{y}_{i j}$ : the value-added production and business sector $i$ in Bantaeng Regency expressed by the value of GDP.

The SLQ calculation results can be used to identify potential sectors in Bantaeng Regency with the following criteria:

$>\mathbf{S L Q}_{i j}>\mathbf{1}$ indicates that the sector $i$ is the dominant sector because the sector is more specialized than the same sector in the South Sulawesi Province;

$>\mathbf{S L Q}_{i j}=\mathbf{1}$ indicates that the sector $i$ has the same level of specialization in these industries in the South Sulawesi Province, so the sector is only enough to meet the needs of its territory alone;

$>\mathbf{S L Q}_{i j}<\mathbf{1}$ indicates that the sector is less specialized than the same sector in the South Sulawesi Province, so it is not a dominant sector.

However, the SLQ method has drawbacks, namely the criteria are merely static, which only provide a snapshot at one point in time. That is, an economy sector that is superior in any given year may not necessarily be the leading economy sector in the next year. Conversely, an economy sector that does not excel in any given year, can be a leading economy sector in the years to come. Therefore, as an alternative method, the method used in this analysis Dynamic Location Quotient (DLQ). The DLQ equation is:

$\left.D L Q_{i j}=\left\{\left[\left(1+g_{i j}\right) /\left(1+g_{j}\right)\right] /\left[1+G_{i}\right) /(1+G)\right]\right\}^{\mathrm{t}}$

Where:

$\mathrm{DLQ}_{i j}$ : potential economy index for sector $i$ in Bantaeng Regency;

$\mathrm{g}_{i j}$ : the growth rate of value-added production and business for sector $i$ in Bantaeng Regency;

$\mathrm{g}_{j}$ : the average GDP growth rate for Bantaeng Regency;

$\mathrm{G}_{i}$ : the growth rate of value-added production and business for sector $i$ in South Sulawesi Province;

G: the average GDP growth rate for South Sulawesi Province.

The DLQ calculation result can be used to identify potential economy sectors in Bantaeng Regency with the following criteria:

$\mathbf{D L} \mathbf{Q}_{i j}>\mathbf{1}$ indicates that the potential for economy development in sector $i$ in Bantaeng Regency is faster compared to the potential development of the same economy sector in South Sulawesi Province (sector $i$ has the potential to become a dominant sector in Bantaeng);

$\mathbf{D L Q}_{i j}=\mathbf{1}$ indicates that the potential for economy development in Bantaeng Regency sector $i$ is equal to the potential development of the same economy sector in South Sulawesi Province;

$>\mathbf{D L Q}_{i j}<\mathbf{1}$ indicates that the potential for economy development in the sector i Bantaeng slower than the economy development potential of the same sector in of South Sulawesi Province (sector $i$ is not potential to become a leading economy sector in Bantaeng Regency).

\section{2) The Classification of Potential Economy sectors}

The classification method of potential economy sectors in Bantaeng Regency is as shown in Table 1 below. 
Table 1. Classification of potential economy sectors in bantaeng regency according to the analysis of static location quotient and dynamic location quotient

\begin{tabular}{lll}
\hline & SLQ $>1$ & SLQ $<1$ \\
\hline DLQ $>1$ & Base Sector & Prospective Sector \\
DLQ $<1$ & Reliably Sector & Lag Sector \\
\hline
\end{tabular}

Where:

$>$ Base sector value is the SLQ $>1$ and the DLQ $>1$, which means that the sector (at the time of the analysis) is a sector that is leading sector (the base sector) and will remain a leading sector (a base sector) for the next few years;

Prospective sector value is the SLQ $<1$ and the DLQ $>1$, which means that the sector (at the time of the analysis) is not a leading sector, but it will remain a leading sector for the next few years;

Reliably sector value is the SLQ $>\mathbf{1}$ and the DLQ $<\mathbf{1}$, which means that the sector (at the time of analysis) is a leading sector, but for the next few years it will not be a leading sector;

Lag sector value is the SLQ $<1$ and the $\mathbf{D L Q}<\mathbf{1}$, which means that the sector (at the time of the analysis) is not a leading sector and it still will not be a leading sector for the next few years.

\section{Result And Discussion}

3.1 The result and Discussion of the Static Location Quotient for the Year 2013

The result of Bantaeng Regency SLQ for the year 2013 is shown in Table 2 below.

Table 2. Static location quotient (SLQ) value of bantaeng regency for the year 2013

\begin{tabular}{|c|c|c|c|}
\hline Industrial Origin & SLQ Value & $\begin{array}{l}\text { Base or Non } \\
\text { Sector }\end{array}$ & Base \\
\hline Agriculture, Forestry, Fishery & 1,57 & Base & \\
\hline Mining and Excavation & 0,36 & Non Base & \\
\hline Processing Industry & 0,31 & Non Base & \\
\hline Procurement of Electricity and Gas & 1,32 & Base & \\
\hline Procurement of Water; Garbage Processing, Waste and Recycle & 0,57 & Non Base & \\
\hline Construction/Building & 1,44 & Base & \\
\hline Wholesale and Retail Trade; Cars and Motorcycle Repair & 1,01 & Base & \\
\hline Transportation and Warehousing & 0,25 & Non Base & \\
\hline Procurement of Accommodation; Food and Drink & 0,51 & Non Base & \\
\hline Information and Communication & 0,45 & Non Base & \\
\hline Financial Service and Insurance & 0,65 & Non Base & \\
\hline Real Estate & 1,25 & Base & \\
\hline Corporate Service & 0,37 & Non Base & \\
\hline Government Administration, Defence and Compulsive Social Security & 1,40 & Base & \\
\hline Education Service & 1,06 & Base & \\
\hline Health Service and Social Activity & 1,36 & Base & \\
\hline Other Service & 1,19 & Base & \\
\hline
\end{tabular}

Source: Researcher calculation, 2016

Based on Table 2, it is noted that there are nine economic base sectors in Bantaeng Regency for the year 2013, i.e.:

* Agriculture, Forestry, Fishery;

* Procurement of Electricity and Gas;

* Construction/Building;

* Wholesale and Retail Trade; Cars and Motorcycle Repair;

* Real Estate;

* Government Administration, Defence and Compulsive Social Security; 
* Education Service;

* Health Service and Social Activity;

* Other Service.

This means that the nine sectors of the economy are able to meet the needs of Bantaeng Regency and able to export products and venture out of Bantaeng Regency.

3.2 The Result and Discussion of the Static Location Quotient for the Year 2014

The result of Bantaeng Regency SLQ for the year 2013 is shown in Table 3 below.

Table 3. Static location quotient (SLQ) value of bantaeng regency for the year 2014

\begin{tabular}{lll}
\hline Industrial Origin & SLQ Value & $\begin{array}{l}\text { Base or Non } \\
\text { Sector }\end{array}$ \\
\hline Agriculture, Forestry, Fishery & 1,50 & $\begin{array}{l}\text { Base } \\
\text { Non Base }\end{array}$ \\
Mining and Excavation & 0,39 & Non Base \\
Processing Industry & 0,34 & Base \\
Procurement of Electricity and Gas & 1,08 & Non Base \\
Procurement of Water; Garbage Processing, Waste and Recycle & 0,63 & Base \\
Construction/Building & 1,44 & Base \\
Wholesale and Retail Trade; Cars and Motorcycle Repair & 1,03 & Non Base \\
Transportation and Warehousing & 0,28 & Non Base \\
Procurement of Accommodation; Food and Drink & 0,59 & Non Base \\
Information and Communication & 0,46 & Non Base \\
Financial Service and Insurance & 0,67 & Base \\
Real Estate & 1,32 & Non Base \\
Corporate Service & 0,39 & Base \\
Government Administration, Defence and Compulsive Social Security & 1,43 & Base \\
Education Service & 1,05 & Base \\
Health Service and Social Activity & 1,34 & Base \\
Other Service & 1,25 &
\end{tabular}

Source: Resercher calculation, 2016.

Based on Table 3, it is noted that only the values of SLQ are different, but the nine base sectors of Bantaeng Regency unchanged. Thus, it can be said that there is no change in the condition of the leading sectors in Bantaeng Regency for the year 2014.

3.3 The Result and Discussion of the Static Location Quotient for the Year 2015

The result of Bantaeng Regency SLQ for the year 2013 is shown in Table 4 below.

Table 4. Static location quotient (SLQ) value of bantaeng regency for the year 2014

\begin{tabular}{lll}
\hline Industrial Origin & SLQ Value & $\begin{array}{l}\text { Base or Non } \\
\text { Sector }\end{array}$ \\
\hline Agriculture, Forestry, Fishery & 1,40 & Base \\
Mining and Excavation & 0,57 & Non Base \\
Processing Industry & 0,36 & Non Base \\
Procurement of Electricity and Gas & 1,21 & Base \\
Procurement of Water; Garbage Processing, Waste and Recycle & 0,64 & Non Base \\
Construction/Building & 1,36 & Base \\
Wholesale and Retail Trade; Cars and Motorcycle Repair & 1,05 & Base \\
Transportation and Warehousing & 0,32 & Non Base \\
Procurement of Accommodation; Food and Drink & 0,68 & Non Base \\
Information and Communication & 0,47 & Non Base \\
Financial Service and Insurance & 0,66 & Non Base \\
Real Estate & 1,36 & Base \\
\hline
\end{tabular}




\begin{tabular}{lll}
\hline Industrial Origin & SLQ Value & $\begin{array}{l}\text { Base or Non Base } \\
\text { Sector }\end{array}$ \\
\hline Corporate Service & 0,38 & Non Base \\
Government Administration, Defence and Compulsive Social Security & 1,37 & Base \\
Education Service & 1,05 & Base \\
Health Service and Social Activity & 1,47 & Base \\
Other Service & 1,30 & Base \\
\hline
\end{tabular}

Source: Resercher calculation, 2016.

Based on Table 4, it is noted also that only the values of SLQ are different, but the nine base sectors of Bantaeng Regency unchanged. Thus, it can be said that there is also no change in the condition of the leading sectors in Bantaeng Regency for the year 2015.

\subsection{The Result and Discussion of the Dynamic Location Quotient}

The Dynamic Location Quotient calculation results for the period of 2013-2014 and 2014-2015 are shown in Table 5 below:

Table 5. Dynamic location quotient value for economy sectors in Bantaeng regency for the period of year 2013-2014 and 2014-2015

\begin{tabular}{lll}
\hline Industrial Origin & $\mathbf{2 0 1 3 - 2 0 1 4}$ & $\mathbf{2 0 1 4 - 2 0 1 5}$ \\
\hline Agriculture, Forestry, Fishery & 0.59 & 0.32 \\
Mining and Excavation & 1.25 & 12.51 \\
Processing Industry & 1.54 & 1.36 \\
Procurement of Electricity and Gas & -1.00 & 0.27 \\
Procurement of Water; Garbage Processing, Waste and Recycle & 9.78 & 1.03 \\
Construction/Building & 0.92 & 0.57 \\
Wholesale and Retail Trade; Cars and Motorcycle Repair & 1.03 & 1.10 \\
Transportation and Warehousing & 1.64 & 1.93 \\
Procurement of Accommodation; Food and Drink & 1.97 & 2.37 \\
Information and Communication & 1.30 & 1.14 \\
Financial Service and Insurance & 1.14 & 0.79 \\
Real Estate & 1.31 & 1.13 \\
Corporate Service & 1.33 & 0.91 \\
Government Administration, Defence and Compulsive Social Security & 1.08 & 0.72 \\
Education Service & 0.80 & 0.91 \\
Health Service and Social Activity & 0.83 & 1.52 \\
Other Service & 1.24 & 1.21 \\
\hline
\end{tabular}

Source: Resercher calculation, 2016.

From Table 5 it can be seen that there are twelve leading economy sectors in Bantaeng Regency for the period of the Year 2013-2014 and there are ten leading economy sectors for the period of the Year 2014-2015.

\subsection{The Classification of the Potential Economy Sectors}

The classification of the potential economy sectors of Bantaeng Regency for the Year 2013-2014 is shown in Table 6. 
Table 6. Potential economy sectors classification of Bantaeng regency for the period 2013-2014

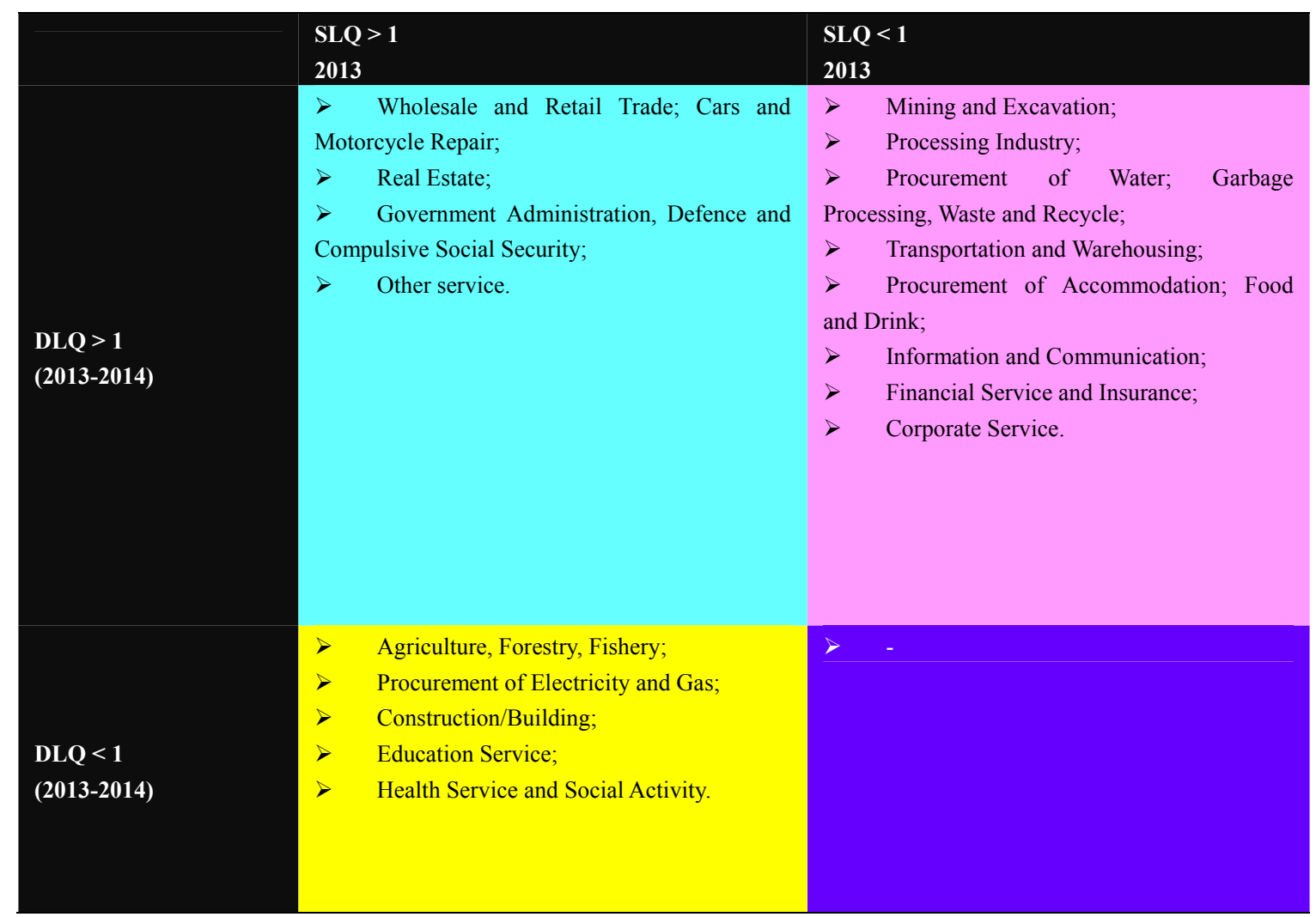

Source: Processed by the Researcher, 2016.

Table information:

\begin{tabular}{|ll}
\hline$:$ & Base Sector \\
$:$ & Prospective Sector \\
$:$ & Reliably Sector \\
\hline & Lag Sector
\end{tabular}

From Table 6 it can be seen that in Bantaeng Regency for the period 2013-2014, there were four leading economy sectors, eight prospective economy sectors, five reliably sectors of the economy and no lagging sector of the economy.

Furthermore, potential economy sectors classification of Bantaeng Regency for the period 2014-2015 is shown in Table 7 below:

Table 7. Potential Economy Sectors Classification of Bantaeng Regency for the Period 2014-2015

\begin{tabular}{|c|c|c|}
\hline & $\begin{array}{l}\text { SLQ > 1 } \\
2014\end{array}$ & $\begin{array}{l}\text { SLQ }<1 \\
2014\end{array}$ \\
\hline $\begin{array}{l}\text { DLQ }>1 \\
(2014-2015)\end{array}$ & $\begin{array}{l}>\text { Wholesale and Retail Trade; Cars } \\
\text { and Motorcycle Repair; } \\
>\quad \text { Real Estate; } \\
>\quad \text { Health Service and Social } \\
\text { Activity; } \\
>\quad \text { Other service. }\end{array}$ & $\begin{array}{l}>\quad \text { Mining and Excavation; } \\
>\quad \text { Processing Industry; } \\
>\quad \text { Procurement of Water; Garbage } \\
\text { Processing, Waste and Recycle; } \\
>\quad \text { Transportation and Warehousing; } \\
>\quad \text { Procurement of Accommodation; } \\
\text { Food and Drink; } \\
>\quad \text { Information and Communication. }\end{array}$ \\
\hline
\end{tabular}




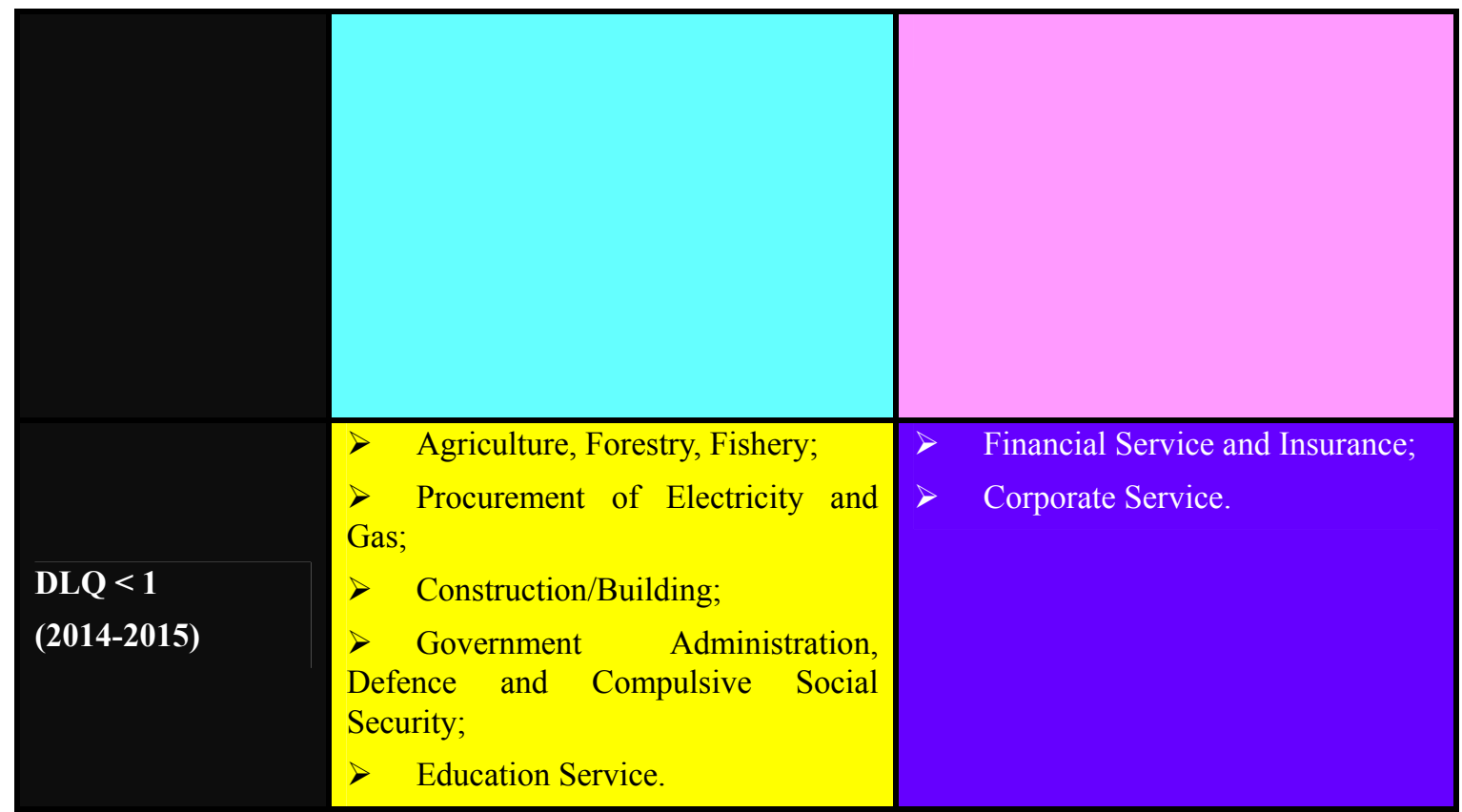

Source: Processed by the Researcher, 2016

\section{Table information:}

\begin{tabular}{|ll}
\hline$:$ & Base Sector \\
$:$ & Prospective Sector \\
$:$ & Reliably Sector \\
\hline$:$ & Lag Sector
\end{tabular}

With the same concept, from Table 7 it can be seen that in Bantaeng Regency for the period 20140-2015 there were four leading economy sectors, six prospective economy sectors, the mainstay of the five economy sectors and two lag economy sectors.

\section{Conclusion}

Having regard to the calculation and analysis SLQ and DLQ that have been done, then the mapping of potential economy sectors Bantaeng Regency is as follows:

\section{1) Leading (Base)Economy Sectors:}

i. For the period 2013-2014:

$>\quad$ Wholesale and Retail Trade; Cars and Motorcycle Repair;

$>$ Real Estate;

$>$ Government Administration, Defence and Compulsive Social Security;

$>$ Other service.

ii. For the period 2014-2015:

$>\quad$ Wholesale and Retail Trade; Cars and Motorcycle Repair;

$>$ Real Estate;

$>$ Health Service and Social Activity;

$>$ Other service.

2) Prospective Economy Sectors:

i. For the period 2013-2014:

$>$ Mining and Excavation; 
Processing Industry;

$>$ Procurement of Water; Garbage Processing, Waste and Recycle;

$>$ Transportation and Warehousing;

$>$ Procurement of Accommodation; Food and Drink;

$>$ Information and Communication;

$>$ Financial Service and Insurance;

$>$ Corporate Service.

ii. For the period 2014-2015:

Mining and Excavation;

$>$ Processing Industry;

$>$ Procurement of Water; Garbage Processing, Waste and Recycle;

$>$ Transportation and Warehousing;

$>$ Procurement of Accommodation; Food and Drink;

$>$ Information and Communication.

3) Reliably Economy Sectors:

i. For the period 2013-2014:

$>$ Agriculture, Forestry, Fishery;

$>$ Procurement of Electricity and Gas;

$>$ Construction/Building;

$>$ Education Service;

$>$ Health Service and Social Activity.

ii. For the period 2014-2015:

$>$ Agriculture, Forestry, Fishery;

$>$ Procurement of Electricity and Gas;

$>$ Construction/Building;

$>$ Government Administration, Defence and Compulsive Social Security;

$>$ Education Service

4) Lag Economy Sectors:

i. For the period 2013-2014:

ii. For the period 2014-2015:

$>$ Financial Service and Insurance;

$>$ Corporate Service.

\section{References}

Arsyad, L. (1992). Economy development. Part Publishing STIE YKPN. Yogyakarta.

BPS. (2016). Bantaeng In Figures. The Central Bureau of Statistics for Bantaeng Regency Press.

Creswell, J. W. (2009). Research Design: Qualitative, Quantitative, and Mixed Methods Approaches (3rd ed.). Sage Publications, California.

Ethridge, Don. (1995). Research Methodology in Applied Economics. Iowa State University Press, Ames, Iowa.

Fitanto, B. and Pratomo, D. S. (2004). Model Location quotients and Shift-Share in the Regional Economic Planning (Empirical Study On Three districts in East Java). Journal of Social Sciences, 16(2).

Hendayana, R. (2003). Application Methods Location Quotient (LQ) in the determination of national commodities. Journal of Agricultural Informatics, 12.

Jhingan, M. L. (2014). Economy development and Planning. Rajawali Press, Jakarta. 
Kamaluddin, R. (1992). Anthology of National Development and Regional Development. LP3SE. Jakarta.

Kuncoro, M. (2004). Autonomy and Local Development: Reform, Planning, Strategy and Opportunities. Erlangga. Jakarta.

Nazipawati. (2007). Application of Static and Dynamic Location Quotient and Shift-Share Model In Regional Economic Planning: Case Study for Ogan Komering Ulu Regency in South Sumatra Province. Eko-Regional Journal, 2(2).

Rachbini, D. J. (2001). Economy development and Human Resources. Gramedia Widiasarana Indonesia, Jakarta.

Yuwono, P. (2000). Planning and Development Policy Analysis $1^{\text {st }}$ ed. Faculty of Economics, University Christian Satya Discourse. Salatiga.

\section{Copyrights}

Copyright for this article is retained by the author(s), with first publication rights granted to the journal.

This is an open-access article distributed under the terms and conditions of the Creative Commons Attribution license (http://creativecommons.org/licenses/by/4.0/). 